\title{
Effect of Nigella Sativa (Kalozira) Oil on Pain in Long Evans Rats
}

\author{
Ismoth Ara Jerin ${ }^{1}$, Noorzahan Begum ${ }^{2}$
}

\begin{abstract}
Background: For thousands of years, Nigella sativa has been used in many countries as a spice as well as a protective and curative remedy for numerous health disorders. Nigella sativa oil (NSO) suppressed pain in animal models. Objective: To assess the effects of Nigella sativa oil on pain after single administration with three increasing doses in rat models. Methods: This experimental study was conducted in the Department of Physiology, Bangabandhu Sheikh Mujib Medical University (BSMMU), Dhaka, from March 2016 to February 2017. For this, 20 (twenty) Long Evans rats (200 \pm 20 ) of both sexes were divided into control ( $10 \mathrm{ml} / \mathrm{kg}$ of $1 \%$ solution of Tween 20 ) and experimental groups (NSO 0.5 , with $0.5 \mathrm{ml} /$ $\mathrm{kg} \mathrm{NSO}$; NSO 1, with $1 \mathrm{ml} / \mathrm{kg} \mathrm{NSO}$; NSO 1.5, with $1.5 \mathrm{ml} / \mathrm{kg} \mathrm{NSO}$ ) with 5 rats in each group.. To assess nociceptive pain, central analgesic system and inflammatory pain ,early phase $\left(1^{\text {st }}-5^{\text {th }}\right.$ minutes $)$; inter phase $\left(6^{\text {th }}-15^{\text {th }}\right.$ minutes $)$ and on late phase $\left(16^{\text {th }}-60^{\text {th }}\right.$ minutes $)$ of formalin test respectively were observed. All the agents were given intraperitoneally in a single dose just one hour before the formalin test. In all phases, total frequency of jerking and total duration of flexing and licking of right hind paw were counted after administration of subcutaneous formalin $(50 \mu \mathrm{L}, 2.5 \%)$ injection. Statistical analysis was done by ANOVA, followed by Bonferroni's post hoc test.. Results: In early phase, NSO significantly reduced the jerking ( $\mathrm{p} \leq 0.001$, in all doses) and flexing and licking ( $\mathrm{p} \leq 0.001$, in higher 2 doses). In interphase, jerking was significantly $(\mathrm{p} \leq 0.01)$ lowered after $1.5 \mathrm{ml} / \mathrm{kg}$ of NSO but flexing and licking were significantly lowered by at all 3 doses $(p \leq 0.05, p \leq 0.001, p \leq 0.001$,). In addition, in late phase jerking and flexing and licking were reduced by higher 2 doses ( $\leq 0.001$, ) and all 3 doses respectively ( $\leq \leq 0.001$, in all doses). Conclusion: From this study, it may be concluded that, NSO possess analgesic effect and higher two doses were more effective than lower doses.
\end{abstract}

Keywords: Pain, Nigella sativa, Tail immersion test, Formalin test.

J Bangladesh Soc Physiol. 2018, June; 13(1): 1-7 For Authors Affiliation, see end of text.

http://www.banglajol.info/index.php/JBSP DOI: http://dx.doi.org/10.3329/jbsp.v13i1.37840

\section{Introduction}

$\mathbf{P}$ ain is a subjective experience which also involves emotional and cognitive components $^{1-3}$. Though it alerts about actual or potential tissue damage but because of its discomfort and distress- forces one to consult a physician $^{4-5}$. Etiologically it has been classified

Received 11 Feb. 2018; Accepted 12 April 2018

J Bangladesh Soc Physiol. 2018, June; 13(1): 1-7 into nociceptive, inflammatory, neuropathic and functional types ${ }^{3,6-8}$.

To measure the nociceptive pain, different nociceptive tests involving different types of stimuli (electrical, thermal, mechanical or chemical) are used ${ }^{9}$. The formalin test is a commonly used method for the assessment of nociceptive pain in animal models ${ }^{10}$. This test 
shows an early phase interphase and late phase reflecting direct activation of nociceptors, activation of central analgesic system and inflammatory pain respectively ${ }^{11,12}$.

Various analgesics used for pain relief posseses lot of unwanted effects like gastritis, gastric ulcers and renal damage ${ }^{13}$. In recent years, invetigations are continuing globally to find out alternatives to the traditional analgesic drugs to replace them so that their adverse effect can be minimized.

Nigella sativa (Kalozira) is an annual herb of the Ranunculaceae family. Since ancient period, this plant has been recognized in many Asian, Middle Eastern and Far Eastern countries as a spice and food preservative as well as a protective and health remedy for numerous health disorders. Previous studies demonstrated antinociceptive and anti-inflammatory effect of Nigella sativa, in animal models ${ }^{14-18}$. Recently, both single and long term supplementation of Nigella sativa has demonstrated its good protective effects against nociceptive pain $^{17,19}$.

Oral administration of Nigella sativa oil $(50,100,200$ and $400 \mathrm{mg} / \mathrm{kg})$ dose dependently has been found attenuated the nociceptive responses in hot-plate test, tail pinch test and the early phase of formalin test in a study ${ }^{16}$. The volatile oil of Nigella sativa $(100,200,400 \mathrm{iL} / \mathrm{kg}$,i.p) has been found to produce significant analgesic effect in writhing, formalin and light tail flick test on mice ${ }^{17}$. Although oral administration of this volatile oil at doses of 100,200 , and $400 \mathrm{iL} / \mathrm{kg}$ did not exert a significant anti-inflammatory effect, intraperitoneal injection of the same doses significantly inhibited carrageenan induced rat paw edema ${ }^{18}$.

However, no reported data was available on investigating the effect of NSO intraperitoneally on nociceptive and inflammatory pain.

Therefore this study has been designed on observe the dose dependent effect of NSO on nociceptive and inflammatory pain by intraperitoneal administration of 3 increasing dose on rat.

\section{Methods}

This experimental study was conducted in the Pain Laboratory, Department of Physiology, Bangabandhu Sheikh Mujib Medical University (BSMMU), Dhaka from March 2016 to February 2017. All experiments and animal care were performed according to the guidelines set in the 'The ethical guidelines for experimentation in laboratory animals' by the Animal Experimentation Ethics Committee (AEEC) of the International Centre for Diarrhoeal Disease Research, Bangladesh (ICDDRB 2002) ${ }^{20}$.

Procurement and maintenance of animals:

Twenty healthy adult Long Evans rats weighing 180 to 220 gm of either sexes ${ }^{17,21}$ were collected from animal house of Bangladesh University of Health Sciences (BUHS), Darussalam, Mirpurone (1), Dhaka.

They were housed in the Pain Laboratory of the Department of Physiology, BSMMU, in specially built plastic cages with 5 rats per cage under a $12 / 12$ hour light/dark cycle ${ }^{22-24}$. The ambient room temperature was maintained at around $27-28^{\circ} \mathrm{C}$, corresponding to the thermoneutral zone for rodents $25-, 26$. The rats had free access to standard laboratory food and cooled boiled water ad libitum. They were kept there for a period of seven consecutive days for acclimatization prior to the experiment. To avoid circadian influences all the experiments were performed at daytime between 08:00 and 15:00 hours $^{27}$.

Dose schedule:

The Nigella sativa oil manufactured by Drug International Pharmaceuticals, Bangladesh was dissolved in 1\% solution of Tween 20 (Techno Pharmaceuticals, India). On the basis of doses of supplementation all the rats were divided into 4 groups ( 5 rats/ group). The control group received only $1 \%$ solution of Tween $20(10 \mathrm{ml} / \mathrm{kg}$ body weight $)^{18}$, experimental Groups NSO I, NSO

J Bangladesh Soc Physiol. 2018, June; 13(1): 1-7 
II and NSO III received $0.5 \mathrm{ml} / \mathrm{kg}, 1 \mathrm{ml} / \mathrm{kg}$ and 1.5 $\mathrm{ml} / \mathrm{kg}$ body weight of Nigella sativa oil respectively, in equal volume to that of $1 \%$ solution of Tween $20^{28}$. All the agents were given through the intraperitoneal route (i.p) one hour before the formalin tests ${ }^{18,28}$.

Formalin test:

For acclimatization to the test environment, the rats were placed in the observation chamber (34 x 34 x $34 \mathrm{~cm}^{3}$ ) of the Plexi glass formalin test box in pairs for fifteen (15) minutes daily for four (4) days, and singly for three (3) days prior to the test ${ }^{11,12}$. On the day of experiment, the rat was intraperitoneally injected with $1 \%$ solution of Tween 20 or Nigella sativa oil $0.5 \mathrm{ml} / \mathrm{kg}$ or $1 \mathrm{ml} /$ $\mathrm{kg}$ or $1.5 \mathrm{ml} / \mathrm{kg}$ body weight, in accordance with the experimental paradigm being followed. One hour later, the rat was restrained manually by a thick towel and the right hind paw was exposed. Fifty il of dilute $(2.5 \%)$ formalin was injected subcutaneously ${ }^{12}$ into the plantar aspect of the right hind paw with an insulin syringe. Instantly thereafter, the animal was placed in the observation chamber of the Plexiglass formalin test box, and pain behaviours were observed for 60 minutes. A mirror fixed at an angle of 45 degrees beneath the transparent floor of the chamber was

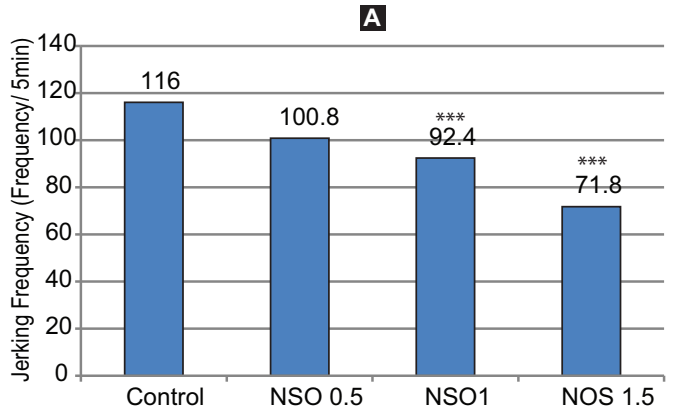

used to facilitate unhindered observation. The first 5 minutes (1st-5th) was considered as the early or acute phase, the next10 minutes (6th15 th) as the interphase, and the last 45 minutes (16th-60th) as the late phase. During observation, the total number of jerking and the total duration of flexing plus licking and/or biting of the injected paw (in seconds) were recorded. A stop watch was used to count the time $11,12,23$.

The results were expressed as mean \pm SEM. The data were statistically analyzed by ANOVA, followed by Bonferroni's post hoc test. In the interpretation of results, $\mathrm{p} d$ " 0.05 was considered as the level of significance.

\section{Results}

The effects of NSO at three increasing doses $(0.5,1$ and $1.5 \mathrm{ml} / \mathrm{kg}$; i.p) on pain were observed in early and late phase of formalin test. Also the central analgesic activity was observed in interphase of formalin test.

In early phase

NSO at all 3 doses $(0.5,1,1.5 \mathrm{ml} / \mathrm{kg})$ significantly (pd"0.001) lowered number of jerking whereas duration of flexing and licking was significantly $(\mathrm{p} \leq 0.001)$ lowered by only at higher doses $(1,1.5 \mathrm{ml} / \mathrm{kg})$ of NSO.

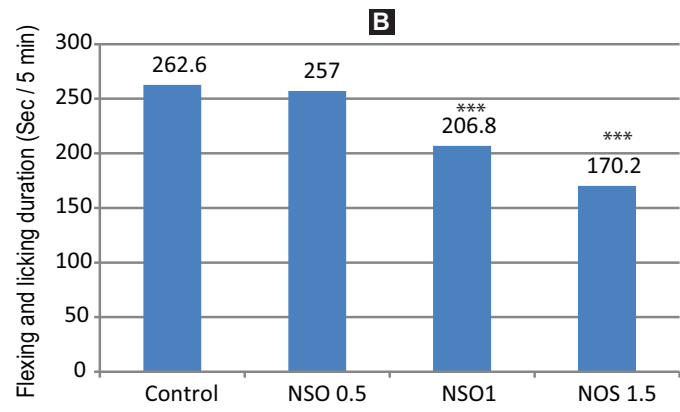

Figure 1: Frequency of jerking (A) and duration of flexing and licking (B) in early phase of formalin test in different groups of rats. Control $=1 \%$ solution of Tween $20(10 \mathrm{ml} / \mathrm{kg}$ body weight $)$; NSO $0.5=$ Nigella Sativa Oil $0.5 \mathrm{ml} / \mathrm{kg}$ body weight; NSO 1= Nigella Sativa Oil $1 \mathrm{ml} / \mathrm{kg}$ body weight; NSO 1.5= Nigella Sativa Oil $1.5 \mathrm{ml} / \mathrm{kg}$ body weight. Each bar symbolizes for mean for 5 rats. $* * *=p \leq 0.001$, compared to control. 
In interphase

NSO only at dose of $1.5 \mathrm{ml} / \mathrm{kg}$ significantly $(\mathrm{p} \leq 0.01)$ lowered the frequency of jerking. Again, NSO at all 3 doses significantly and dose dependently reduces the duration of flexing and licking.
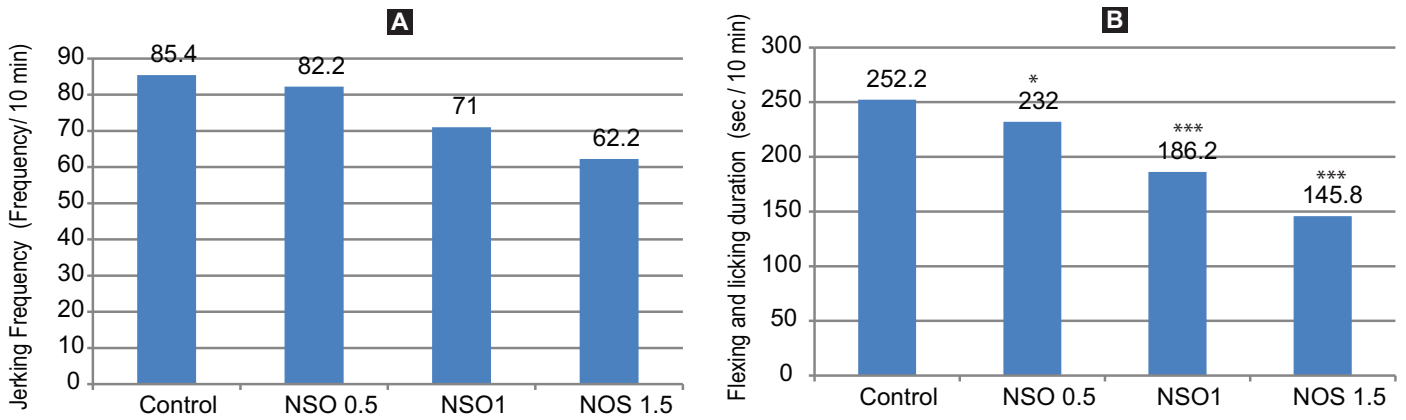

Figure 2: Frequency of jerking (A) and duration of flexing and licking (B) in interphase of formalin test in different groups of rats. Control=1\% solution of Tween $20(10 \mathrm{ml} / \mathrm{kg}$ body weight $)$; NSO $0.5=$ Nigella Sativa Oil $0.5 \mathrm{ml} / \mathrm{kg}$ body weight; NSO 1= Nigella Sativa Oil $1 \mathrm{ml} / \mathrm{kg}$ body weight; NSO 1.5= Nigella Sativa Oil $1.5 \mathrm{ml} / \mathrm{kg}$ body weight. Each bar symbolizes for mean. $* * *=\mathrm{p} \leq 0.001, * *=\mathrm{p} \leq 0.01$, $*=\mathrm{p} \leq 0.05$ compared to control.

\section{In late phase}

$\mathrm{NSO}$ at doses of $1 \mathrm{ml} / \mathrm{kg}$ and $1.5 \mathrm{ml} / \mathrm{kg}$ significantly $(\mathrm{p} \leq 0.001)$ reduced both the frequency of jerking and duration of flexing and licking. Again, NSO at dose of $0.5 \mathrm{ml} / \mathrm{kg}$ only reduced the duration of flexing and licking significantly $(\mathrm{p} \leq 0.001)$.

A

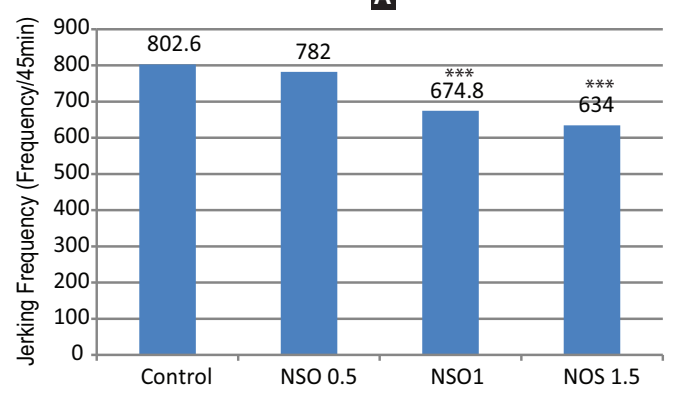

B

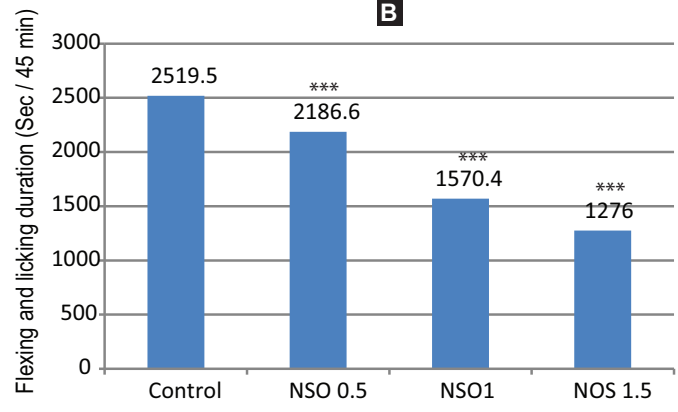

Figure 3: Frequency of jerking (A) and duration of flexing and licking $(\mathrm{B})$ in late phase of formalin test in different groups of rats. Control=1\% solution of Tween $20(10 \mathrm{ml} / \mathrm{kg}$ body weight $)$; NSO $0.5=$ Nigella Sativa Oil $0.5 \mathrm{ml} / \mathrm{kg}$ body weight; NSO 1= Nigella Sativa Oil $1 \mathrm{ml} / \mathrm{kg}$ body weight; NSO 1.5= Nigella Sativa Oil $1.5 \mathrm{ml} / \mathrm{kg}$ body weight. Each bar symbolizes for mean for 5 rats. $* * *=\mathrm{p} \leq 0.001$, compared to control.

\section{Discussion}

In this study, the nociceptive pain variables were lowered in all three study groups after intraperitoneal administration of Nigella Sativa
Oil $(0.5,1,1.5 \mathrm{ml} / \mathrm{kg}$; i.p) in comparison to that of control. Similar trends of decrement of nociceptive pain with increment of doses of Nigella sativa were also observed by previous

J Bangladesh Soc Physiol. 2018, June; 13(1): 1-7 
researchers in different animal studies though the doses were different from this study 16,18, 29 .

Again, Nigella Sativa Oil only at a dose of 1.5 $\mathrm{ml} / \mathrm{kg}$ (i.p) significantly enhanced central analgesic activity as evidenced by decrease in the frequency of jerking in interphase of formalin test. Again, duration of flexing and licking in interphase of formalin test was significantly lowered in all three study groups than that of control.

All three doses of Nigella Sativa Oil significantly lowered inflammatory pain variables compared to that of control. However, the frequency of jerking in late phase of formalin test was significantly lowered only at doses of $1 \mathrm{ml} /$ $\mathrm{kg}$ (i.p) and $1.5 \mathrm{ml} / \mathrm{kg}$ (i.p) in comparison to control group. There was significant decrement in duration of flexing and licking with the increment of doses in late phase of formalin test.. These findings agree the findings of other investigators who observed similar dose dependent reduction of inflammatory pain after supplementation of Nigella sativa though the doses were different from this study $16,18,29$.

The exact mechanism by which the Nigella sativa cause analgesic and anti-inflammatory effect is not clear from this study. However, several researchers proposed various mechanisms on these aspects. The Nigella sativa oil might exert antinociceptive effect through the action on opioid receptors. The analgesic activity of Nigella sativa oil was antagonized by opioid antagonists (Naloxone) ${ }^{30,16}$. It has also been suggested that, Nigella sativa oil might act through indirect activation of the supraspinal ì 1 and š opioid recptor ${ }^{16}$. Opioid receptors are located on the terminals of nociceptive neuron in the spinal cord and on the dendrites of dorsal horn neurons. It might cause presynaptic inhibition by inhibiting the adenylyl cyclase enzyme and reducing the $\mathrm{Ca}^{++}$influx in the nociceptive afferent neuron. This in turn may decrease the release of glutamate and substance

J Bangladesh Soc Physiol. 2018, June; 13(1): 1-7
$\mathrm{P}$ from these neurons. In addition, it also might increase the $\mathrm{K}^{+}$conductance in the dorsal horn neuron (postsynaptic neuron) and causes hyperpolarization of these neurons. Both these actions might decrease the duration of EPSP in the dorsal horn neuron, finally leading to decreased pain conduction ${ }^{31}$.

Numerous molecular targets are involved in the anti-inflammatory activity of Nigella sativa. Nigella sativa oil might act by inhibiting histamine release from mast cells ${ }^{32}$. Several researchers proposed that, the anti-inflammatory effect of Nigella sativa oil is due to its potent inhibition on eicosanoid generation ${ }^{33,34}$. It might cause a concentration dependent inhibition of 5lipoxygenase products and 5-HETE production 34. Nigella sativa might reduce inflammatory pain by inhibiting production of IL- $1 \alpha, 35,36$ TNF- $\alpha$ 35,36 and $\mathrm{PGE}_{2}{ }^{36}$.

\section{Conclusion}

In the present study, intraperitoneal administration of Nigella sativa oil at three different doses were effective in lowering pain.It is also evident that higher dose was more effective than the lower dose of NSO. Therefore, it may be concluded that increasing dose of Nigella sativa oil was progressively more effective in lowering pain and inflammation, as observed in this study.

Conflict of interest The authors declare no conflict of interest.

Author affiliations

*1. Dr. Ismoth Ara Jerin, Assistant Professor, Department of Physiology, Jalalabad Ragib Rabeya Medical college, Sylhet, Bangladesh. email: ismothara777@gmail.com

2. Dr. Noorzahan Begum, Former Professor, Department of Physiology, Bangabandhu Sheikh Mujib Medical University (BSMMU), Bangladesh. email:noorzahan52@gmail.com

* For correspondence

\section{Acknowledgement:}

This study received a research grand from the education ministry of Bangladesh. 


\section{References}

1. Melzack R. The tragedy of needless pain. Sci Am 1990; 262(2): 27-33.

2. Julius D, Basbaum AI. Molecular mechanisms of nociception. Nature 2001; 413:03-10.

3. Woolf CJ. Pain: moving from symptom control toward mechanism-specific pharmacologic management. Ann Intern Med 2004; 140:41-51.

4. Abbott FV, Fraser MI. Use and abuse of over-thecounter analgesic agents. J Psychiatry Neurosci 1998; 23(1):13-34.

5. Turk DC, Dworkin RH. What should be the core outcome of clinical pain trials? Arthritis Res. Ther 2004; 6(4):51-4.

6. Eli I, Svensson P. The multi-dimensional nature of pain. In: Bergenholtz G, Horsted-Binslev P, Reit C, editors. Textbook of endodontology. $2^{\text {nd }} e d$. Chichester: Wiley-Blackwell; 2009.

7. Loeser JD, Treede RD. The kyoto protocol of IASP basic pain terminology. Pain 2008; 137(3):473-77.

8. Woolf CJ. What is this thing called pain? J clin invest $2010 ; 120(11): 3742-44$.

9. Le Bars D, Gozariu M, Cadden SW. Animal models of nociception. Pharmacol Rev 2001; 53(4):597652 .

10. Dubuisson D, Dennis SG. The formalin test: a quantitative study of the analgesic effects of morphine, meperidine, and brain stem stimulation in rats and cats. Pain 1977; 4(2):161-74.

11. Henry JL, Yashpal K, Pitcher GM, Coderre TJ. Physiological evidence that the 'interphase' in the formalin test is due to active inhibition. Pain 1999; 82:57-3.

12. McNamara CR, Brehm et al. TRPA1 mediates formalin-induced pain. Proceedings of the National Academy of Sciences 2007;104 (33): 13525-30.

13. Bashir MU, Qureshi HJ. Analgesic effect of Nigella sativa seeds extract on experimentally induced pain in Albino mice. J coll phys sur Pak 2010; 20(7):464-67.

14. Abdel-fattah AM, Matsumoto K, Watanabe H. Antinociceptive effects of Nigella sativa oil and its major component, thymoquinone, in mice. Eur $\mathrm{J}$ Pharmacol 2000; 400(1):89-97.
15. Al-Ghamdi MS. The anti-inflammatory, analgesic and antipyretic activity of Nigella sativa. J Ethnopharmacol 2001; 76:45-8.

16. Hajhashemi V, Ghannadi A, Jafarabadi H. Black Cumin Seed Essential Oil, as a Potent Analgesic and Antiinflammatory Drug. Phytother Res 2004; 18:195-9.

17. Celik MF, Gocmez MC, Karaman MH, Kamasak MK, Kaplan MI, Akil ME, Tufek MA, Guzel MA. Therapeutic Effects of Thymoquinone in a Model of Neuropathic Pain. Cur Ther Res. 2014; 76:11-6.

18. Islam KMN, Rahman ASMH, Al-Mahmud KA. Manual for care and use of laboratory animals. Animal resources branch. International Centre for Diarrhoeal Disease Research, Bangladesh; 2001.

19. Tanko Y, Mohammed A, Okasha MA, Shuaibu A, Magaji MG, Yaro AH. Analgesic and antiinflammatory activities of ethanol seed extract of Nigella sativa (Black Cumin) in mice and rats. Eur J Sci Res 2007; 18(2):271-81.

20. Abbott FV, Franklin KB, Westbrook RF . The formalin test: scoring properties of the first and second phases of the pain response in rats. Pain 1995; 60(1):91-102.

21. Tajik H, Tamaddonfard E, Hamzeh-Gooshchi N (2008). The effect of curcumin (active substance of turmeric) on the acetic acid-induced visceral nociception in rats. Pak J Biol Sci 11(2):312-4.

22. Ali T, Javan M, Sonboli A, Semnanian S. Evaluation of the antinociceptive and anti-inflammatory effects of essential oil of Nepeta pogonosperma jamzad et assadi in rats. DARU 2012; 20:1-8.

23. Refinetti R \& Horvath SM. Thermopreferendum of the rat: inter- and intra-subject variabilities. Behav Neural Biol1989; 52(1):87-94.

24. França et al. Induce an antinociceptive effect in the acetic acid and formaldehyde models of nociception in mice. Eur J Pharmacol 2001; 421:157-64.

25. Moallem SA, Hosseinzadeh H, Farahi S. A study of acute and chronic anti-nociceptive and antiinflammatory effects of thiamine in mice. Iran Biomed J 2008; 12 (3):173-8.

26. Rahman AFMT, Islam MS, Ali MH, Alam AHMK, Abdur-Rahman MA, Sadik MG, Rashid M. Nigella sativa Oil Potentiates the Effects of Pioglitazone on Long Term Alloxan-Induced Diabetic Rats. Ban Pharmaceu J 2013; 16(2): 143-51.

J Bangladesh Soc Physiol. 2018, June; 13(1): 1-7 
27. Ghannadi A, Hajhashemi V, Jafarabadi H. An investigation of the Analgesic and Antiinflammatory effects of Nigella sativa seed polyphenols. J Med food 2005; 8 (4):488-93.

28. Khanna T, Zaidi FA, Dandiya PC. CNS and analgesic studies on Nigella sativa. Fitoterapia. 1993; 64:407-10.

29. Barrett KE, Barman SM, Boitano S, Brooks HL. Ganong's review of medical physiology. 25th ed. New Delhi: Tata McGraw-Hill; 2016.

30. Chakravarty N. Inhibition of histamine release from mast cells by nigellone. Ann Allergy 1993; 70(3):237-42.

31. Houghton PJ, Zarka R, De las Heras B, Hoult RS. Fixed oil of Nigella sativa and derived thymoquinone inhibit eicosanoid generation in leukocytes and membrane lipid peroxidation. Planta Medica1995; 61(1):33-6.

32. El-Dakhakhny M, Madi NJ, Lembert N, Ammon HPT. Nigella sativa oil, nigellone and derived thymoquinone inhibit synthesis of 5-lipoxygenase products in polymorphonuclear leukocytes from rats. J Ethnopharmacol 2002; 81(2):161-4.

33. Tekeoglu I, Dogan A, Ediz L, Budancamanak M, Demirel A. Effects of thymoquinone (volatile oil of black cumin) on rheumatoid arthritis in rat models. Phytother Res 2007; 21(9):895-7.

34. Vaillancourt F, Silva P, Shi Q, Fahmi H, Fernandes $\mathrm{JC}$, Benderdour M. Elucidation of molecular mechanisms underlying the protective effects of thymoquinone against rheumatoid arthritis. J Cell Biochem 2011; 112:107-17. 